\title{
Measurement of lipid profile parameters in hypertensive patients using atenolol or captopril
}

\author{
Ahmed Yahya Dallal Bashi*, Rawaa Khazal Jaber**, Mohammed Khalid Al. Hamo*** \\ * Department of Medical Biochemistry, College of Medicine; ** Specialist in Clinical Biochemistry, \\ Al-Khansa Maternity Hospital; *** Department of Medicine, College of Medicine, University of Mosul.
}

(Ann. Coll. Med. Mosul 2010; 36 (1 \& 2): 41-48).

Received: $19^{\text {th }}$ Sept 2010; Accepted: $9^{\text {th }}$ Feb 2011.

\begin{abstract}
Objectives: To study the effects of atenolol and captopril on lipid profile parameters including total cholesterol (TC), triglycerides (TG), High density lipoprotein cholesterol (HDL-c), Low density lipoprotein cholesterol (LDL-c) and atherogenic index (AI) in serum. Moreover to compare the effects of these drugs on the above parameters with each other.

Patients and Methods: One hundred hypertensive patients were involved in this study which were divided into two groups each of 50 patients. Patients in the first group were on atenolol and the patients in the second group were on captopril. All of the cases of hypertension were of the primary type (essential) as the patients were diagnosed by specialist physicians. The patients included were not chronically using any other drugs, nor having family history of hyperlipidemia, and not suffering from any other chronic disease.

The ages of the patients in the first group ranged from 35-74 years with a mean of $55 \pm 5.02$ years, while the ages of the second group ranged from $36-80$ years with a mean of $57 \pm 6.0$ years. Another group of 50 normal individuals participated in this study as a control group, with ages ranged from 3572 years with a mean of $53 \pm 4.4$ years.

Results: The results of this study showed that serum TG and Al were significantly higher in atenolol using group in comparison with the control group, while serum HDL-c concentration was significantly lower. Whereas, the remaining lipid profile parameters studied were not significantly different from the control group. Serum LDL-c concentration was significantly low in captopril using group compared with the control group whereas the remaining lipid parameters studied were not significantly changed in this group. Further analysis of the results of the present study indicated significant decreases of serum TG and Al in captopril using group in comparison with Atenolol using group. Whereas, serum HDL-C concentration was significantly higher in captopril using group.

Conclusion: The overall analysis of the lipid profile parameters studied might suggest that atenolol has certain undesirable effects on these parameters while captopril has less undesirable effects. This might indicate that captopril seems to be more suitable antihypertensive agent than atenolol for patients with lipid profile abnormalities.
\end{abstract}

Keywords: Serum, lipid profile, triglyceride, total cholesterol, HDL-C, LDL-c, atherogenic index, hypertension.

الخلاصة

الأهداف: لمعرفة تأثير عقاري الاتنولول و الكابتوبريل على بعض فحوصات واجهة الثحوم في مصل الدم تتشل ( تركيز

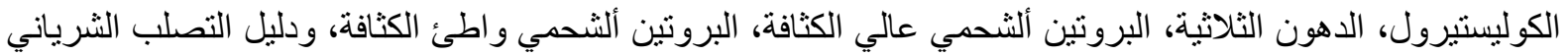

في مصل الدم). 
المرضى و الطرق: أجريت هذه الدر اسة على مائة مريض مصابين بفرط ضغطط الدم. وقد تم تقسيم المرضى إلى مجمو عتين

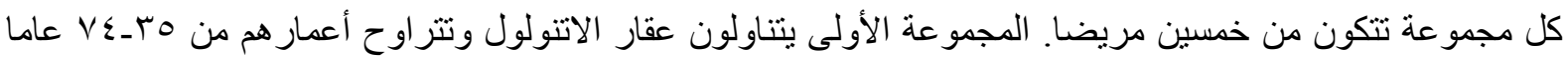

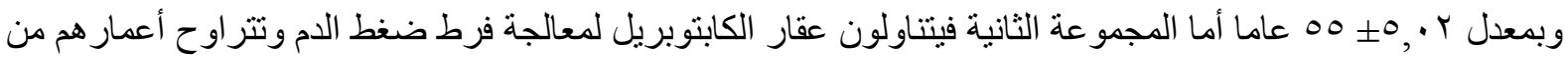

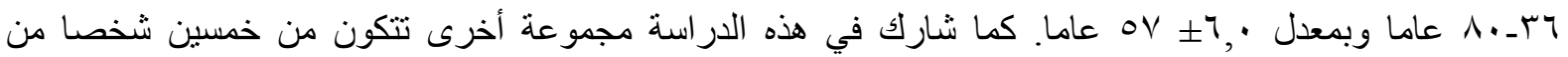

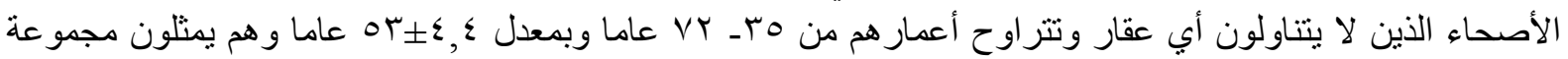
الضبط. جميع المرضى المشمولين بهذه الدر اسة مصابين بضغط الدام الابتدائي ومشخصين من قبل الأبن الأطباء الاختصاصيين

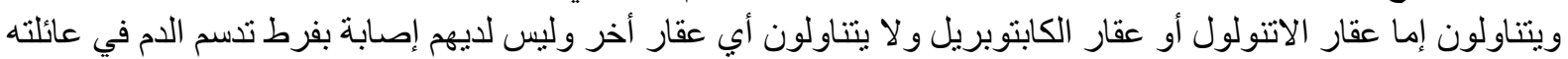

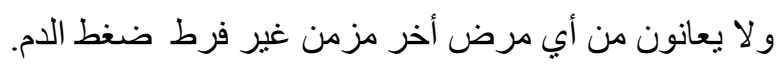

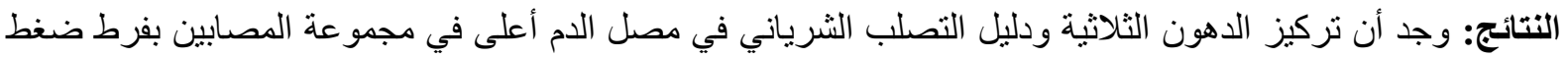

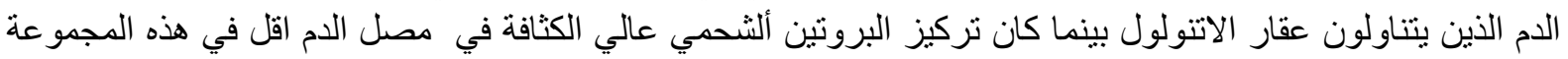
عند مقارنتها بمجمو عة الضبط.

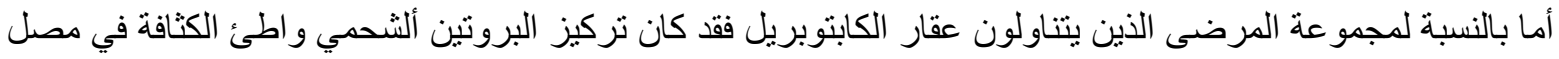

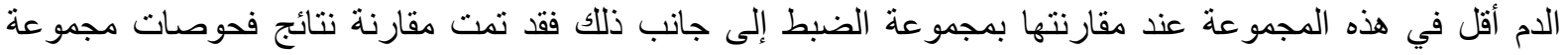

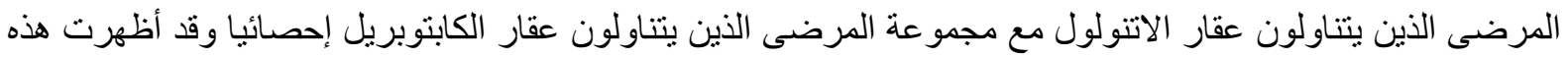

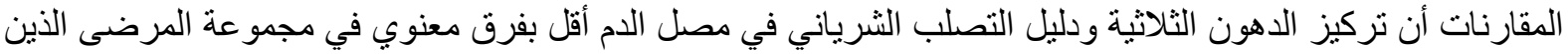
يتناولون عقار الكابتوبريل مقارنة بمجمو عة المرضى الذين يتناولون عقار الاتنولول. من جهة أخرى فان فئن تركيز البروتين

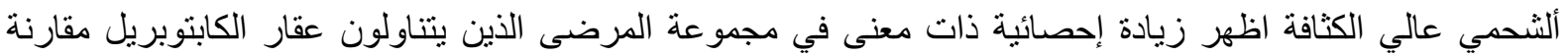

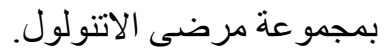

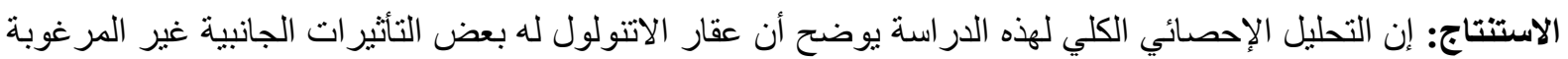

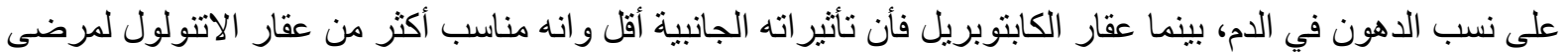
فرط ضغط الدم خاصة المصابين بخلل في تر اكيز الدهون في مصل الدان.

A $n$ elevation of the systolic and/or diastolic blood pressure increases the risk of developing heart diseases, kidney diseases, hardening of the arteries, eye damage, and even stroke (brain damage) might happen ${ }^{(1)}$.

The objective of treating a systemic arterial hypertension is to reduce the risk of complications and to improve survival ${ }^{(2)}$.

The commonly used anti hypertensive drugs include a lot of drugs with different mechanism of action. In this study the two most popular antihypertensive drugs were chosen which are atenolol and captopril ${ }^{(3)}$.

Atenolol, a synthetic, $\beta 1$-selective (cardio selective) adreno receptor blocking agent is prescribed for patients with high blood pressure $^{(4)}$. Nowadays, the use of beta blockers was downgraded as antihypertensive therapy from the first line treatment to the fourth line as they perform less well than other new drugs, particularly in elderly ${ }^{(5)}$.
Captopril is characterized by the presence of sulfhydryl group in its structure, it is an ACE inhibitor ${ }^{(6)}$. The mechanism of action is by blocking the rennin angiotensin system, that inhibit the conversion of the inactive angiotensin I to the powerful vasoconstrictor and stimulator of aldosterone release, angiotensin II. This effect results in decrease of peripheral vascular resistance and also a reduction in the level of the sodium retaining hormone aldosterone ${ }^{(7)}$.

The aim of this study is to find the effects of atenolol and captopril on certain lipid profile parameters including serum; total cholesterol (TC), triglycerides (TG), High density lipoprotein cholesterol (HDL-C), Low density lipoprotein cholesterol (LDL-C) and atherogenic index (Al). Moreover to compare the results of the effects of the drugs studied on the above parameters with each other in order to assess the relative safety of each in comparison to the other. 


\section{Patient and methods \\ Patients}

This study was approved by ethical committee in the College of Medicine and Local Health Authority. One hundred hypertensive patients of both sexes were included in this study during a period of 8 months from October 2007 till June 2008. Half of the patients were controlled using the antihypertensive drug "captopril" in doses ranging from 25-150 $\mathrm{mg} /$ day. The duration of treatment ranged from 6 months to 15 years and their ages ranged from $36-80$ years with a mean of 57 years.

The other half of patients were controlled by using the antihypertensive drug "Atenolol" in a dose ranging from $50-100 \mathrm{mg} / \mathrm{day}$. The duration of treatment ranged from 6 months to 20 years and their ages ranged from $35-74$ years with a mean of 55 years.

Patients with a history of hepatic, cardiac or any other diseases which may interfere with this study were excluded. Also any patient who takes drugs other than captopril or atenolol were also excluded. Moreover diabetic patients, alcoholics, and those with a family history of hyperlipidemia were also excluded from the study.

\section{Control}

Fifty apparently healthy individuals aged 35 72 years with a mean of $53 \pm 4.4$ years of both sexes were included in this study as a control group (the consent of each volunteer was taken to give a sample of his blood to be used as a control). All factors which might interfere with the study were excluded just like that of the patient's groups.

\section{Specimens and methods}

Overnight fasting blood samples were obtained from all subjects included in this study by antecubital venepuncture.

Five milliliters $(5 \mathrm{ml})$ of venous blood sample from each patient were collected in a plain tube, allowed to clot for 15 minutes in a water bath at $37{ }^{\circ} \mathrm{C}$. Serum was separated by centrifugation at $3000 \mathrm{rpm}$ for 15 minutes to ensure complete separation of the serum.

Each sample of serum was used for the measurement of certain lipid profile parameters as mentioned. The samples were stored at $-20{ }^{\circ} \mathrm{C}$ until analysis was done on daily basis. For accuracy and reproducibility internal quality control (QC) of pooled serum was used within the run and within the batch through out the study.

All biochemical analysis was performed at the laboratory of higher study in the Department of Biochemistry, Mosul Collage of Medicine, University of Mosul.

Serum Total cholesterol (TC) concentration was determined by enzymatic method ${ }^{(8)}$, using a kit supplied by Biomerieux company (France).

Serum triglycerides (TG) was estimated by enzymatic method ${ }^{(9)}$, using a kit supplied by Biomerieux company (France).

Serum high density lipoprotein cholesterol (HDL-c) was determined by enzymatic method $^{(10)}$, using a kit supplied by Biomerieux company (France).

Serum low density lipoprotein cholesterol (LDL-C) is calculated according to the following equation ${ }^{(11)}$ :

LDL-C= total cholesterol- (HDL-C)-TG/5 (mg/dl)

Atherogenic index $(\mathrm{Al})$ was calculated by the following equation ${ }^{(12)}$ :

$\mathrm{Al}=$ Total serum cholesterol $/ \mathrm{HDL}-\mathrm{c}$.

\section{Statistical analysis}

The experimental data were subjected to Analysis of Variance, Duncan Multiple Range Tests, and Trend Analysis using Statistical Analysis System (SAS) according to Littlell et al., (13).

\section{Results}

Table (1) and figure (1) show the results of comparing lipid profile parameters between the control group and each of the other groups of hypertensive patients using atenolol or captopril.

TC: No significant decrease was observed by comparing the means of total serum cholesterol between the group using atenolol and the control group. The same results found when comparing total cholesterol in the group using captopril and the control group (Table 1, Fig 1).

HDL-c: The mean of serum HDL-c in atenolol using group showing a highly significant decrease $(P<0.001)$, while serum HDL-C 
showing no significant decrease in captopril using group in comparison with the control group (Table 1, Fig 1).

LDL-C: The mean of serum LDL-c showing a no significant change in atenolol using group in comparison with the control group, while in captopril using group there is a significant decrease in the mean of serum LDL-C $(P \leq 0.05)$ (Table 1, Fig 1).

Al: In the comparison of $\mathrm{Al}$ in atenolol using group with control group there is a significant increase in atenolol using group ( $P<0.001)$, while that of captopril group showing no significant change with that of control group (Table 1, Fig 1).

TG: The comparison of serum TG in atenolol using patients group with control group showing a significant increase in the mean of serum TG in atenolol using group ( $P \leq 0.05$ ), while the comparison in captopril using group and the control showing no significant increase in the mean of serum TG (Table 1, Fig 1).

Table (1): Showing a comparison of some lipid profile parameters between control group and each of hypertensive patient's groups using atenolol or captopril.

\begin{tabular}{|l|c|c|c|}
\hline \multirow{2}{*}{ Parameters } & \multicolumn{3}{|c|}{ Mean \pm SD } \\
\cline { 2 - 4 } & Control & $\begin{array}{c}\text { Atenolol } \\
\text { using group }\end{array}$ & $\begin{array}{c}\text { Captopril } \\
\text { using group }\end{array}$ \\
\hline $\begin{array}{l}\text { TC } \\
\text { (mmol/L) } \\
\text { Range }\end{array}$ & $5.29 \pm 0.83$ & $5.27 \pm 1.25$ & $4.94 \pm 1.06$ \\
\cline { 2 - 4 } & $3.77-6.99$ & $3.30-8.50$ & $2.78-8.09$ \\
\hline $\begin{array}{l}\text { TG } \\
\text { (mmol/L) }\end{array}$ & $1.66 \pm 0.70$ & $2.00 \pm 0.85^{*}$ & $1.68 \pm 0.55$ \\
\cline { 2 - 4 } Range & $0.61-2.96$ & $0.90-4.42$ & $0.41-3.53$ \\
\hline $\begin{array}{l}\text { HDL-c } \\
\text { (mmol/L) }\end{array}$ & $1.32 \pm 0.20$ & $1.08 \pm 0.21^{* *}$ & $1.24 \pm 0.22$ \\
\cline { 2 - 4 } $\begin{array}{l}\text { Range } \\
\text { RDL-C } \\
\text { (mmol/L) }\end{array}$ & $0.78-1.80$ & $0.78-1.61$ & $0.90-1.79$ \\
\cline { 2 - 4 } Range & $1.77-5.08$ & $1.70-5.67$ & $1.73-5.13$ \\
\hline Al & $4.12 \pm 1.01$ & $5.00 \pm 1.34^{* *}$ & $4.09 \pm 0.93$ \\
\cline { 2 - 4 } & $2.50-8.20$ & $2.40-8.30$ & $2.70-6.80$ \\
\hline Range
\end{tabular}

* Significant difference from control group at $p \leq 0.05$ and ${ }^{* *}$ at $p<0.001$ using unpaired Z-test
Table (2) showing a comparison of lipid profile parameters between hypertensive patients groups using atenolol and captopril.

The means of serum TC and LDL-C showing no significant change in captopril using group from that of atenolol using group.

The means of serum HDL-C and Al showing significant decrease in captopril using patient's group from that of atenolol using patient's group $(P<0.001)$.

The mean of serum TG showing a significant decrease in captopril using patient's group from that of atenolol using patient's group ( $P$ $\leq 0.05)$.

Table (2): Showing a comparison of some lipid profile parameters between hypertensive patient's using atenolol and captopril.

\begin{tabular}{|c|c|c|c|}
\hline \multirow{2}{*}{$\begin{array}{c}\text { Parameters } \\
\text { (Serum) }\end{array}$} & \multicolumn{2}{|c|}{ Mean \pm SD } & \multirow[b]{2}{*}{$p$-value } \\
\hline & $\begin{array}{c}\text { Atenolol } \\
\text { using group }\end{array}$ & $\begin{array}{c}\text { Captopril } \\
\text { using group }\end{array}$ & \\
\hline $\mathrm{TC}(\mathrm{mmol} / \mathrm{L})$ & $5.27 \pm 1.25$ & $4.94 \pm 1.06$ & $\begin{array}{l}0.163 \\
(\mathrm{NS})\end{array}$ \\
\hline $\mathrm{TG}(\mathrm{mmol} / \mathrm{L})$ & $2.00 \pm 0.85$ & $1.68 \pm 0.55$ & $0.028^{*}$ \\
\hline $\begin{array}{l}\text { HDL-c } \\
(\mathrm{mmol} / \mathrm{L})\end{array}$ & $1.08 \pm 0.21$ & $1.24 \pm 0.22$ & $<0.001^{* *}$ \\
\hline $\begin{array}{l}\text { LDL-C } \\
(\mathrm{mmol} / \mathrm{L})\end{array}$ & $3.25 \pm 1.07$ & $2.92 \pm 0.64$ & $\begin{array}{l}0.065 \\
(\mathrm{NS})\end{array}$ \\
\hline $\mathrm{Al}$ & $5.00 \pm 1.34$ & $4.09 \pm 0.93$ & $<0.001^{* *}$ \\
\hline
\end{tabular}

*Significant difference from control group at $p \leq 0.05$ and ${ }^{* *}$ at $p<0.001$ using unpaired Z-test

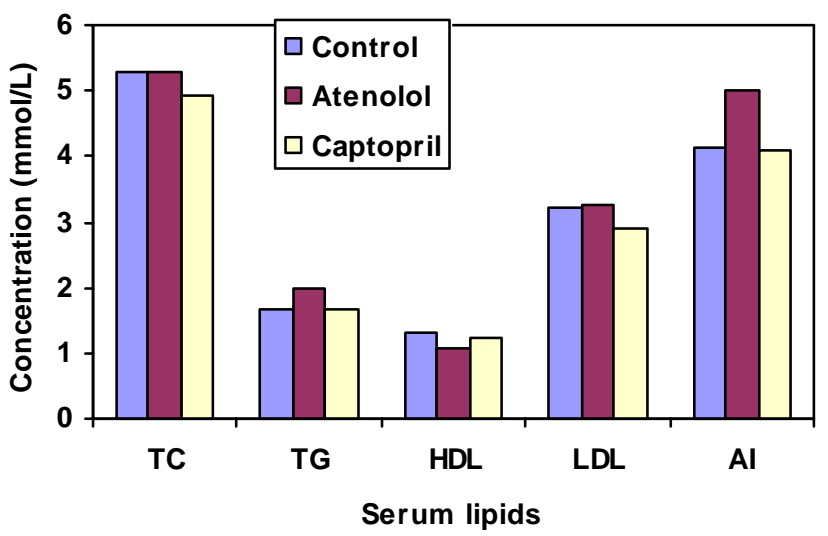

Figure (1): Histogram showing some lipid profile parameters for control group and each of hypertensive patients groups using atenolol or captopril. 


\section{Discussion}

In this study, the value of serum total cholesterol is found to be within normal level in patient's group using atenolol in comparison with control group. This result is in agreement with the result of the study reported by another author ${ }^{(14)}$ who studied the effects atenolol on hypertensive patients and found that there is no significant change in TC in patients who used atenolol.

In other words, prolonged administration of atenolol in the recommended dose by hypertensive patients has no adverse effects on TC, meaning that atenolol has no effect on cholesterol metabolism. The mechanism of this action for $\beta$-blockers on lipid parameters is still not understood ${ }^{(15)}$.

The result of the present study showed that HDL-c is significantly lower in patient's group using atenolol in comparison with control group. This result agrees with that of many authors who found that $\beta$-blockers cause decrease in serum HDL-c ${ }^{(15,16,17)}$.

The decrease in serum HDL-C might be accounted to be due to the inhibitory effect of $\beta$ - blockers on lipoprotein lipase ${ }^{(18)}$. LPL is essential for the transfer of phospholipids and apo-lipoproteins to HDL-c ${ }^{(19)}$. Others suggested that atenolol might decrease serum apo-lipoprotein type Al which is the principle constituent of HDL-C that is associated with enhanced reflux of cholesterol from arterial wall ${ }^{(20)}$.

When serum LDL-c concentration is compared between the patient's group using atenolol and the control group, it is found that there is an increase in the mean of serum LDL-C in atenolol using patient's group in comparison with the control group but this increase does not reach to significant level. This result agrees with that of other studies where atenolol indicated to has no significant effect on LDL-c ${ }^{(15,17)}$.

On the other hand, the present result disagrees with certain study where it is found that serum LDL-C concentration increased significantly in patients used $\beta$ - blockers. This difference might be attributed to the long period of treatment in those patients ${ }^{(18)}$.
The slight increases in the level of serum LDL-C concentration might be explained by the effect of atenolol on serum apo-lipoprotien B which is suggested to be increased by atenolol administration ${ }^{(21)}$.

The level of $\mathrm{Al}$ is significantly higher in Atenolol using patient's group in comparison with the control group. This result is in agreement with the result obtained by other authors who found that atenolol causes a significant increase in total cholesterol / HDL-c ratio( i.e. $\mathrm{Al}$ ) ${ }^{(22)}$, that might be explained by the significant change in serum HDL-c level by atenolol in the present study.

The comparison of serum TG level in patient's group using atenolol with the control group shows that there is a significant increase in serum TG level in those using atenolol. This result is in agreement with that result of other authors where they found that atenolol causes hypertriglyceridemia ${ }^{(18,23)}$.

On the contrary, the result of this study is in contrast with results obtained by others who found that atenolol has no significant effects on TG ${ }^{(14)}$. The effect of atenolol on serum TG may be accounted by that the blockage of $\beta$ adrenergic receptor might affect serum lipoproteins and the plasma enzymes involved in the metabolism of serum lipoproteins like lipoprotein lipase, hepatic lipase and lecithin cholesterol acyl transferase ${ }^{(16,18,24)}$. A more clear account suggested that as LPL is a ratelimiting enzyme in the lipolysis of plasma TGrich lipoproteins and is bound to glycosaminoglycans on the surface of the endothelium in muscles and adipose tissues. The hydrolytic function of LPL is essential for the processing of TG-rich lipoproteins and VLDL to remnant particles and for transfer of phospho-lipids and apo-lipoprotiens to HDL-C $(25,26)$.

Another opinion that the effects of $\beta$-blockers in inhibiting LPL activity could be due to altered LPL gene transcription and / or translation of lipoprotein lipase mRNA or could be an effect at the protein level of the gene ${ }^{(19)}$.

\section{Captopril and lipid profile}

The value of serum TC in patient's group using captopril shows no significant difference in comparison with the control group. This means 
that captopril has no adverse effect on serum total cholesterol. The result of the present study agrees with many other studies which indicate that captopril causes no change in serum TC level ${ }^{(27,28)}$.

In contrast, the result of the present study disagree with the result of studies reported that treatment with captopril caused significant decrease in serum total cholesterol level ${ }^{(29)}$. This difference may be due to the difference in the sample size.

The result of the present study shows no significant difference in serum HDL-c level between captopril using patient's group and the control group. The effects of captopril on lipid profile were studied by many investigators; all showed a similar result to the present study $(27,30)$

In the present study, the result of serum LDLc concentration is compared between patient's group using captopril and the control group. It shows a significant reduction in serum LDL-C concentration. This result agrees with that of others where they found a significant reduction in serum LDL-c level in captopril using patient's group when compared with control ${ }^{(30)}$. The decrease in serum LDL-c level may be accounted to be due to an increase in LDL receptor numbers ${ }^{(30)}$, or may be due to that various substances containing thiol group ($\mathrm{SH}$ ) such as glutathione, acetyl cystein or ACEI (captopril and zofenopril) can inhibit the free radicals production in atherogenesis leading to improving the situation of lipids in the body ${ }^{(31)}$.

The level of atherogenic index (AI) of captopril using patient's group shows no significant difference from the control group. This result agree with that of Alves et al.., ${ }^{(30)}$, who found that there was no significant decrease in the ratio of serum total cholesterol/ serum HDL-c in patients shared in their study, this difference may be due to that in their study the serum TC was significantly decreased by captopril treatment.

The comparison of serum triglycerides level in patient's group using captopril with the control group shows that no significant difference was found. This result is in agreement with the results of the following study done by Scemama et al., ${ }^{(32)}$.

Nevertheless, the result of the present study disagrees with that of other investigators who found that captopril reduced serum TG level $(33,34)$

This effect on serum TG may be accounted for that converting enzyme inhibitors have beneficial effects on insulin and glucose levels that could be expected to favorably influence lipids ${ }^{(35,36)}$.

\section{Conclusion}

The findings, in this study indicate that Atenolol has some undesirable effects on the metabolism of lipids whereas Captopril has less undesirable effects on the metabolism of lipids. Accordingly Captopril may be regarded more suitable antihypertensive drug for patients with hyperlipidemia than Atenolol. We recommend that patients who are on Atenolol treatment should have periodic measurements and follow up of lipid profile parameters.

\section{References}

1. John P, Cunha DO. High blood pressure (hypertension), causes, treatment and medication. e Med Health. 2007; 45: 1723. (Available for VRL,www. Icmje. Org).

2. Boon NA, College NR, Walker BR. Diseases of the cardiovascular system. In: Bloom FP, Baradbury A, Grubb NR. Davidson's Principles and Practice of Medicine, 20th ed. London: Churchill Livingstone; 2006; P. 551-62.

3. Krajten JA, Dunselman S. Nifidipine gastrointestinal therapeutic system in the treatment of coronary heart disease and hypertension. Expert Rev Cardiovasc Ther. 2007; 5: 643-53.

4. Ogbra O. Atenolol. eMedicin. 2007; 49: 115-7. (Available for VRL, www. Icmje. Org).

5. Lavda S. Hypertension guideline. National Institute for health and clinical excellence. 2006; 21: 21-3.

6. Thomas MC. Diuretics, ACE inhibitors and NSAIDs. Med J Aust. 2006; 172(4): 184-5.

7. Ogbra O. ACE inhibitors. Med Net. com. 2003; 112-6. 
8. Virdi NK, Worthington DJ Cholesterol and Triglyceride stability in whole blood .Ann.Clin .Biochem. 1989; 26: 197-8.

9. Fossti P, Prencipe L. Serum Triglycerides determination colorimtrically with an enzyme that produces hydrogen peroxides. Clin. Chem. 1982; 28: 2077-88.

10. Lopez V, Stone P, Ellis S, Cowell JA. Cholesterol determination in $\mathrm{HDL}$ separated by three different methods. Clin Chem. 1977; 23(5): 882-4.

11. Friedewald WT, Levy RJ, Fredrickson DS. Estimation of the concentration of LDL-c in plasma without use of preparative ultracentrifuge. Clin Chem. 1972; 18: 499502.

12. Schulpis K, Karikas GA. Serum Cholesterol and Triglyceride Distribution in 7767 School-aged Greek Children. Pediatric. 1998; 101( 5): 861-4.

13. Littell CR, Walter WS, Rudolf JF. SAS for Linear Models, $4^{\text {th }}$ ed. Cary NC; SAS Institute Inc: USA; 2002.

14. Ghiadoni L, Magagana A, Versari D, Kardasz I, Huang Y, Taddoi S. Salvetti A. Different effect of Antihypertensive Drugs on Conduit Artery Endothelial Function, Hypertension. 2003; 41: 1281- 6.

15. Bosten BR, Dubuque IL, Madison IA. Adrenoceptor antagonist drugs. Basic and Clinical Pharmacology $10^{\text {th }}$ ed. New York, USA: McGraw Hill Company; 2007.

16. Harvengt $C$, Heller FR, Martial $P$, Van $Y$. Short-term effects of beta-blockers atenolol, nadolol, pindolol, propranolol on lipoprotein metabolism in normolipidemic subjects. J Clin Pharmacol. 2007; 17: 4757.

17. Middeke $M$, Richter $W O$, Schwandt $P$, Beck B, Halzgreve $H$. Normalization of lipid metabolism after withdrawal from antihypertensive long-term therapy with beta-blockers and diuretics. J Am Heart Assoc. 2001; 10: 145-7.

18. Rabkin SW. Mechanism of action of adrenergic receptor blockers on lipid during antihypertensive drug treatment. J Clin Pharmac. 2000; 33(3): 286-9.

19. Bjorn E, Michael D, Hallman H, Paul WA, Reymer BSC, Eric G. Genetic variant showing a positive interaction with betablockers agents with beneficial influences on lipoprotein lipase activity. Circulation. 2000; 95: 2628-35.

20. Reneland R, Alvarez E, Andersson PE, Haenni A, Byberg L, Lithell H. Induction of insulin resistance by $\beta$-blockade but not ACE-Inhibition:long-term treatment with atenolol ortrandolapril. J Hum Hypertens. 2000; 14(3): 175-80.

21. Andreas JF, Frank $H$, Peter $W$, Beat $S$. Effect of losartan, compared with atenolol, on endothelial function and oxidative stress in patients with type 2 diabetes and hypertension. J Hypertension. 2007; 25(4): 785-91.

22. Chopra HK, Krishna CK, Ravinder SS,Komal KK. Non-cardiac effects of atenolol. Supplement of JAPI. 2009; 57: 26-8.

23. Theodora G, Demokritos C, Tsoukatos, Loukianos S, Necolas H, Alex D. LDL sub fraction in patient with myocardial infarction: effects of smoking and betablockers. Ann Clin Biochem. 2000; 37: 313-8.

24. Beisiegel $U$, Weber $W$, Bengtsson $B$, Olivecrona G. Lipoprotein lipase enhances the binding of chylomicrons to low density lipoprotein receptor related protein. Proc Natl Acad Sci. 2001; 88: 8342- 6.

25. Lalouel JM, Wilson DE, Iverius $\mathrm{PH}$. Lipoprotein lipase and hepatic triglyceride lipase, molecular and genetic aspect. Curr Opin Lipidol. 2000; 3: 186-95.

26. Olivecrona $\mathrm{T}$, Bengtsson M, Olivecrona G. Lipoprotein lipase and hepatic lipase. Curr Opin Lipidol. 2001; 4: 187-96.

27. Dupuy O, Beauduceau B, Mayandon H. Rilmenidine in the hypertensive type 2 diabetic, a controlled pilot study versus captopril. J Cardiovasc Risk. 2000; 7: 5761.

28. Kourilsky O. Iterium: Clinical benefits from an innovative antihypertensive treatment. J Hypertonie. 2002; 6(4): 10-5.

29. Bertman L, Kasiske K, Jennie Z, Robert S, Kalil N, Thomas A. Effects of antihypertensive therapy on serum lipids. An Intern Med. 2000; 122: 133- 41. 
30. Alves RJ,Diament J, Amancio RF, Forti N, Maranhae R. Lack of effect of captopril on the metabolism of an artifical lipid emulsion similar to chylomicrons in hypertensive hypercholestrolemic patients. Arq Bras cardiol. 2004; 83(6): 512-5.

31. Wojciech W, Jan G, Krzysztof S. The influence of ACE inhibitors on aorta elastin metabolism in diet induced hypercholesterolemia in rabbits. J Renin Angiotens- Aldost Sys. 2001; 1: 37- 41.

32. Scemama M, Fevrier B, Beucler I and Divon F. Lipid profile and antihypertensive efficacy in hyperlipidemia hypertensive patient comparison of rilmenidine and captopril. J Cardiovas Pharmacol. 1996; 26: 34-9.

33. Kost CK, Rominski BR, Herzer WA, Jakson EK, Toforic SP. Persistent improvement of cardiovascular risk factor in spontaneously hypertensive rats following early short term captopril treatment. Clin Exp Hypertens. 2000; 22: 127- 43 .
34. Robert WC. Effects of beta blockers on blood lipid levels. Am Heart J. 2001; 132: 709-14.

35. Berne C. Metabolic effects of ACE inhibitors. J Intern Med. 2000; 239: 11925.

36. Paolisso G, Gambardella A, Verza M, Amor A, Sgambato S, Varricchio M. ACE inhibitors improve insulin sensitivity in aged insulin resistant hypertensive patients. J Hum Hypertens. 2002; 16: 1759. 